\title{
Chronology of key events surrounding the Irish marriage equality campaign ${ }^{1}$
}

1993 Antiquated criminal law relating to homosexuality abolished (7 July)

Protection for lesbian and gay workers enshrined in updated Unfair Dismissals Act (14 July)

1996 Refugee Act includes protection from persecution on grounds of sexual orientation (26 June)

1998 Employment Equality Act protects lesbian and gay workers regarding recruitment and employment (18 June)

1999 Equality Authority established (18 October)

2000 Equal Status Act introduced - protects people against discrimination in the provision of goods and services on nine grounds, including sexual orientation (26 April)

2003 Ann Louise Gilligan and Katherine Zappone marry in Canadian Province of British Columbia (13 September)

2004 Civil Registration Act updated; now includes declaration prohibiting marriage between two people of the same sex (27 February)

KAL (an acronym of the first names of Katherine Zappone and Ann Louise Gilligan) challenge to Revenue Commission granted by Mr Justice Liam McKechnie at the High Court (8 November)

Senator David Norris introduces a Private Members, Civil Partnership, bill in the Seanad (9 December)

2005 Revenue Commissioners and the State file defence to KAL case (May)

Civil partnership introduced in UK, including Northern Ireland (19 December) 
2006 Equality Authority states legal requirement under Belfast Agreement to provide same rights in Republic as in Northern Ireland (January)

Bertie Ahern TD is the first Taoiseach to officially attend a lesbian and gay event - the opening of the Gay and Lesbian Equality Network's (GLEN's) new offices (3 April)

Irish Council for Civil Liberties report, Equality for All Families (April)

Hearing of Zappone \& Gilligan High Court case (3-13 October)

Government Working Group on Domestic Partnership, 'Colley Report', identifies marriage as the only full equality option for same-sex couples (November)

Publication of Labour Party Civil Unions Bill using model suggested by Colley group (December)

2007 Labour Party Civil Unions Bill defeated (20 February)

New coalition government, Fianna Fáil and Green Party, formed in June, commits to civil partnership based on Colley group findings (13 June)

First expert meeting on the recognition of married same-sex couples at European Parliament (November)

2008 Marriage Equality established (February)

The Department of Justice, Equality and Law Reform publishes a draft proposal entitled 'General Scheme of Civil Partnership Bill' (June). ${ }^{2}$

2009 Presentation of full Civil Partnership Bill (26 June)

Civil Partnership Bill introduced and debated in Oireachtas (December 2009/January 2010)

2010 Forty-seven European countries, including Ireland, agree on measures to combat discrimination on grounds of sexual orientation or gender identity (March)

The Civil Partnership and Certain Rights and Obligations of Cohabitants Act 2010 passes with support of all parties; President Mary McAleese signs it into law (July)

Social Welfare Act updated to include provision for civil partners to be treated equally to married couples (December)

Law Reform Commission recommends extension of guardianship rights to children of civil partners (21 December) 
2011 Civil Partnership Act comes into effect on New Year's Day in Ireland (1 January)

New Programme for Government to address omissions from Civil Partnership Act relating to children and certain tax aspects (6 March)

New coalition government formed, Fine Gael and Labour (9 March)

First public civil partnership takes place - positive reception across national media (5 April)

Finance (No. 3) Act introduced by Minister for Finance, Michael Noonan, providing civil partners the same provisions as married couples for tax purposes (June)

Minister for Justice, Alan Shatter, amends citizenship provisions to provide equality for civil partners (July)

Minister Shatter signs an order recognising foreign samesex registered relationships as Irish civil partnerships (December)

2012 Main political parties - Fianna Fáil, Labour, Sinn Féin and the Greens - support moves towards marriage for same-sex couples

Motion passed at Fine Gael Ard Fheis to prioritise marriage equality in Constitutional Convention (31 March)

Employment Equality (Amendment) Bill proposed by Averil Power to protect LGBT employees in religious-run institutions (February; defeated May)

Cian O'Callaghan, elected as mayor of Fingal County Council, Ireland's first openly gay mayor (June)

Cork City Council votes unanimously to support civil marriage for same-sex couples, closely followed by other local authorities around the Republic (July)

Minister for Justice, Alan Shatter, announces he will introduce bill with parenting reforms for lesbian and gay families (November)

Tánaiste, Eamon Gilmore, calls for referendum on marriage equality (13 November)

Chief Justice of Ireland, Mrs Justice Susan Denham, launches guides to civil partnership in the Four Courts (20 December)

Constitutional Convention formally established: a forum of one hundred people tasked with examining numerous 
aspects of the Irish Constitution, including marriage equality (1 December)

2013 Constitutional Convention calls for legal changes to ensure equal status for same-sex couples and their families suggests referendum on the issue of equal access to civil marriage (24 April)

Department of Justice and Equality publishes briefing note on Family Relationships and Children Bill 2013, aiming to create a legal structure and provide clarity on parental rights and duties in diverse family forms (November)

Convention recommendations accepted and government announces a proposed referendum in Spring 2015 (17 December)

2015 Introduction of Children and Family Relationship Act 2015 (12 March)

Referendum to extend marriage to same-sex couples (22 May 2015)

2018 Children and Family Relationship (Amendment) Act 2018 passes both Houses of the Oireachtas to rectify errors with original bill (18 July)

2019 Civil Registration Bill (2019) passed allowing both parents in a female same-sex relationship to be entered on their child's birth certificate (15 May)

Northern Ireland (Executive Formation etc) Act 2019 passed. Northern Ireland Assembly did not reconvene before 21 October 2019, marriage extended to same-sex couples from 13 January 2020 (24 July)

\section{Notes}

1 From amalgamated sources including Íde O'Carroll and Finbar McDonnell, Marriage Equality: Case study, final version (September 2010); and GLEN briefing note on equal access to civil marriage (2013), available at: www.glen.ie/attachments/GLEN_Briefing_Note_on_Equal_Access_ to_Civil_Marriage.pdf (accessed 9 July 2018).

2 The report is available on the Department of Justice, Equality and Law Reform archive site: https://web.archive.org/web/20100110083414/ http://www.justice.ie/en/JELR/Pages/General_Scheme_of_Civil_ Partnership_Bill (accessed 20 August 2019). 